CORRECTIVE MATING METHODS IN CONTEXT OF BREEDING THEORY

F. R. ALLAIRE

Ohio State University and Ohio Agricultural Research and Development Centre, Columbus, Ohio, U.S.A.

Special mating within breed may be conducted by application of selection index theory when non-linear economic weighting exists. Indexing alternative mating pairs evaluate the complementarity of merit with and among traits.

TESTING BLACK-WHITE CATTLE FOR MILK PRODUCTION

AND GROWTH RATE

M. MILOJIC

Faculty of Agriculture University of Belgrade-Zemun, Yugoslavia

This work studies the problem of the making of the rank list of the breeding bulls tested according to the productivity of the daughters for milk and daily gain of their sons. Six bulls of the black-white race were investigated. The test was made by the method $\mathrm{CC}$, in the first lactation of 305 days, in 120 daughters of these bulls. Simultanously, the daily gain has been watched during the fattening period of sons. The fattening lasted from 90 to 365 days age. The same number of sans were investigated.

Milk production of the daughters has been compared to the production of the contemporaries. The daily gains of the sons has been compared to the male animals of the same age.

Based on the data it has been found out that three bulls increased the milk productivity of their daughters (from ro2-I 45 p. Ioo), while other decreased (from 76-98 p. Ioo) compared to the average of the contemporaries. Totally observed three bulls have increased the milk productivity of their daughters as well as the daily gains of the sons. The poorest were two bulls which decreased both milk productivity of their daughters and daily gains of their sons. One bull decreased the milk production but increased daily gain of sons.

\title{
GENETIC COMPONENTS AFFECTING THE INTERVAL BETWEEN CONSECUTIVE INSEMINATIONS
}

\author{
R. BAR ANAN*, K. OSTERKORN**, H. KRÄUSSIICH** and M. HEIMAN** \\ * Ministry of Agriculture Dpt animal husbandry Makirka P. O. Box II, Tel Aviv, Israel \\ **Institut fär Tierzucht und Zuchthygiene Veterinürstr. I3, 8ooo München, B.R.D.
}

I 20,640 between insemination-intervals were analysed for the effects of the sire of the cow and the mating sire on estimates of non-fertilization and early embryonic death (EED). The effect of the mating sire in estimates of EED was near to zero, on the other hand ro p. 10oheritability by the sire of the cow was found for the estimates indicating EED within a few days from fertilization. The linear correlations between these estimates and conception rates were about - 0.43 . It was inferred that these were genetic components in the uterus or the ovum, which caused EED and postponed the return estrus by very few days. 